\title{
TYÖELÄMÄÄN PÄÄSYN JA SIELLÄ PÄRJÄÄMISEN HAASTEET
}

\section{PÄÄKIRJOITUS}

ERJA POUTIAINEN
Työn muodot ja toteutustavat ovat parhaillaan voimakkaassa muutoksessa. Vakituiset työsuhteet vähenevät ja pätkätyöt lisääntyvät. Työntekijältä odotetaan kykyä siirtyä joustavasti työtehtävästä toiseen sekä kykyä omaksua sujuvasti uusia työmuotoja monitehtäväympäristössä työelämän kaikissa vaiheissa. Samaan aikaan hallitusohjelmassa painotetaan työurien pidentämistä niiden alusta, keskeltä ja lopusta.

Tutkimusten perusteella työuupumus on tavallista. Työsuoriutumiselle asetetut odotukset voivat vähitellen muodostua haastaviksi, jopa omassa työtehtävässään pitkään menestyksekkäästi toimineille henkilöille. Miten tässä tilanteessa pärjää henkilö, jonka työkyky on syystä tai toisesta rajoittunut tai jonka sairaus tai vamma estää jatkamasta aiemmassa työtehtävässä?

Täydennyskoulutus tai uudelleenkoulutus parantaa usein henkilön työmarkkina-asemaa. Koulutuksella on oleellinen merkitys silloin kun työkyvyn rajoitteet johtavat tilanteeseen, jossa on pohdittava tarvetta ammatilliseen uudelleenorientaatioon. Tämä voi tarkoittaa omien työtehtävien selvää muokkaamistarvetta, uusien työtehtävien omaksumista tai kokonaan uuden ammatin hankintaa. Koulutuspolkuja on monia, henkilö voi hakeutua itselle relevantille koulutusalalle tavanomaisia väyliä käyttäen. Toimintarajoitteisille henkilöille löytyy myös yhteiskunnan tukemia kouluttautumismahdollisuuksia.

Ammatillinen aikuiskoulutus on yksi varteenotettava aikuisten uudelleenkoulutuksen väylä. Se on rakennettu vastaamaan yhteiskunnan muutoksen tuottamiin haasteisiin, ja siinä on rohkeasti kehitetty uusia kouluttautumisen ja oppimisen muotoja. Tässä numerossa kirjoittaja valottaa väitöstyönsä tuloksiin perustuvassa katsauksessaan ammatillisen aikuiskoulutuksen mahdollisuuksia ja haasteita. Opiskelija-aineksen heterogeenisuus nostetaan kirjoituksessa ammatillisen aikuiskoulutuksen yhdeksi merkittäväksi haasteeksi. Osa opiskelijoista on työelämässä mukana olevia, täydennyskoulutusta hakevia ammattilaisia, kun taas kasvava osa koulutettavista on ilman ammatillista koulutusta olevia pitkäaikaistyöttömiä tai muuten haastavassa elämätilanteessa olevia. Täten opiskelu- ja työelämätaidot näissä ryhmissä ovat hyvin erilaiset. Koulutuksen sujumisen jarruna voivat olla erilaiset oppimisvaikeudet, mutta opintojen edistymisen haasteiden taustalta voi yhtä hyvin löytyä opiskelijoiden tottumattomuus ja vaikeus sopeutua aikuiskoulutuksen moderniin tapaan oppia ja opettaa. Työn ja työhön kouluttautumisen muodot modernisoituvat, mutta kaikki aikuisopiskelijat eivät näytä pysyvän tässä vauhdissa mukana. Kirjoittaja painottaa tutkimustulostensa antavan vahvaa viitettä siitä, että aikuiskoulutuksen erityisen tuen toteutuksessa, sa- 
moin kuin työelämän tukirakenteissa, on merkittäviä kehittämistarpeita.

Toinen tässä numerossa julkaistava katsaus käsittelee työttömien henkilöiden ammatillisen kuntoutuksen tilaa. Varsin suuri osa työttömistä on vamman tai pitkäaikaissairauden aiheuttaman työkykyrajoitteen vuoksi osatyökykyisiä. Tällä hetkellä kaikista osatyökykyisistä työttömistä yli 40 \% on pitkäaikaistyöttöminä. Kuntoutuspalvelut ovat keskeisessä asemassa, kun puhutaan kyseisen ryhmän työllistymistä tukevista toimenpiteistä. Kuitenkin esimerkiksi TE-palvelussa on selvityksen mukaan tällä hetkellä rajalliset mahdollisuudet vastata työttömien ammatillisen kuntoutuksen palveluntarpeeseen. Osatyökykyisille suunnatut kuntoutuspalvelut eivät selvityksen mukaan myöskään ole nykyisellään riittäviä. Tämän vuoden alussa käynnistynyt uudistunut monialainen yhteispalvelu (TYP) parantaa osaltaan työttömienkin monialaisen palveluntarpeen arviointia. Palveluun ohjataan kuitenkin vain osa työttömistä työnhakijoista, joten katsaus nostaa esiin tarpeen kehittää myös muita paikallisia ja alueellisia yhteistyörakenteita ja -käytäntöjä.

Lehden työttömyysteeman nivoutuu myös työelämäosallisuuden kohentamista tavoittelevan hankkeen esittely. Hankekuvauksessa tuodaan esiin teoreettisesti hyvin perusteltu ja mielenkiintoinen asiakaslähtöisen yhteiskehittämisen malli, jossa työelämän ulkopuolella olevien osallisuutta tuetaan asuinympäristössä toteutuvan yhteistoiminnan kautta.

Sote-uudistus mahdollistaa sosiaali- ja terveydenhuollon toimijoiden yhteisen näkökulman kehittämisen työttömien työkyvyn tukemisessa ja kuntoutuspalvelujen organisoinnissa. Sote-palvelujen lisäksi myös TEpalvelut ovat näillä näkymin siirtymässä maakuntien vastuulle, mikä tarjoaa mahdollisuuden palvelujen entistä parempaan yhteensovittamiseen.

Kaikkien kuntoutustarpeessa olevien ihmisten kuntoutuksen kannalta keskeinen toimija tulee seuraavan vuoden aikana olemaan STM:n syksyllä 2016 asettama Kuntoutuksen uudistamiskomitea. Sen tehtävänä on varsin nopealla aikataululla, vain vuoden pituisen toimikauden aikana, tuottaa välineitä pääministeri Juha Sipilän hallituksen ohjelmaan kuuluvan kuntoutuksen kokonaisuudistuksen toimeenpanoa varten. Komitean työ on erittäin tärkeää, joskin kuntoutusalan monimuotoisuuden ja pirstaloituneisuuden vuoksi haastavaa. Kuntoutusalalla työn etenemistä seurataan tarkasti.

Lehden monialaisen luonteen mukaisesti tämä numero käsittelee erilaisia kuntoutuksen aihepiirejä. Numerossa julkaistu tutkimus esittelee sopeutumisvalmennukseen tulevien kuntoutujien odotuksia ja tarjoaa ensiarvoisen tärkeää tietoa aiemmin vähän tutkitusta mutta Suomen kuntoutusvalikossa tavallisesta kuntoutusmuodosta. Saamme lukea myös kuntoutuksen merkityksestä vammaisten nuorten elämässä samoin kuin fysioterapiakoulutuksen nykyisistä käytännöistä. Lukijoita haastetaan myös pohtimaan sosiaalisen kuntoutuksen onnistumisen edellytyksiä.

Lopuksi muistutan lukijoita Helsingissä 24.11.2016 järjestettävästä osallistujille ilmaisesta Kuntoutuksen tutkimusseminaarista. Sen pääluennoijina on keskeisiä kuntoutuksen alan toimijoita. Seminaarissa on mahdollisuus myös tutustua yli 50 suulliseen tai posteriesitykseen ja kuulla kuntoutuksen tutkijoista koostuvan paneelin näkemyksiä kuntoutuksen tutkimuksen tulevista trendeistä. 


\section{KUNTOUTUSAKATEMIA}

\section{Kuntoutuksen uusi aika 10.11.2016}

\section{Miten vastaamme yhteistyöllä muutosten tuomiin haasteisiin?}

Kuntoutuksen palvelujärjestelmällä on kovat muutospaineet. Sen pitäisi pystyä vastaamaan työelämän ja yhteiskunnan muutosten aiheuttamiin uudenlaisiin tarpeisiin. Nykyinen monikanavainen ja eri sektoreille hajautettu kuntoutus on tullut tiensä päähän, eikä se pysty vastaamaan riittävän hyvin kansalaisten palvelutarpeisiin. Tulevaisuuden kuntoutus ankkuroituu ihmisten arkiympäristöön, rakentuu heidän yksilöllisistä palvelutarpeistaan ja vie tavoiteltuun maaliin asti saumattomien palvelukokonaisuuksien ja eri toimijoiden yhteistyön avulla.

Seminaarissa kuulet lupaavista uusista kuntoutuksen palveluista ja toimintamalleista. Seminaari tarjoaa myös ajankohtaistietoa kuntoutuksen uudistamissuunnitelmista ja sen kytkeytymisestä sote-palvelujen, työllisyyden hoidon ja ammatillisen koulutuksen muutokseen.

\section{Ohjelma}

\subsection{Aamukahvit.}

9.00 Tervetuloa!

9.15 Millaisia muutoksia tapahtuu palvelujärjestelmässä?

Avauspuheenvuoro: Kuntoutuksen palvelujärjestelmän uudet suunnat Vanhempi asiantuntija Matti Tuusa, Kuntoutussäätiö

9.45 Miten teemme yhteistyötä kansainvälisesti?

Rifi kansallisen ja kansainvälisen yhteistyön edistäjänä kuntoutuksessa

Pauliina Lampinen, pj. ja Jaakko Harkko, siht.

Rehabilitation International Finnish Committee (Rifi)

10.30 Miten vaikutamme yhdessä kansallisella tasolla?

Kuntoutuskomitean toiminnasta sekä SOTE- uudistuksesta

Pekka Lapinleimu, pj. , Kuntoutusverkosto KUVE

11.15 Lounas

12.00 Kuntoutuksen uudet tuulet, innovaatiot ja kokeilut- työpaja

12.45 Kahvit

13.00 Yhteistyöstä yhteistoimijuuteen kuntoutuksessa-paneelikeckl te

13.45 Loppuyhteenveto

14.00 Seminaari päättyy

\section{Koulutuspaikka}

Kuntoutussäätiö, Pakarituvantie 4, Helsinki

Hinta: $50 €$ (ALV 0\%)

\section{Kysy lisää:}

Julia Anttilainen, koulutuksen vastuuhenkilö projektisuunnittelija

p. 0447813010

julia.anttilainen@kuntoutussaatio.fi 